\title{
港湾等の強閉鎖性海域の貧酸素水塊の発生機構と動態
}

\section{Generation Mechanism and Movement of Hypoxia in Strongly Enclosed Waters of Ports and Harbors}

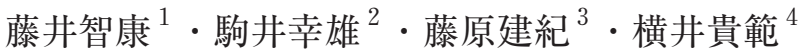 \\ Tomoyasu FUJII, Yukio KOMAI, Tateki FUJIWARA and Takanori YOKOI
}

\begin{abstract}
We conducted field observations in relation to hypoxia which occurs in strongly enclosed waters, such as ports and harbors, and examined generation mechanism and movement of hypoxia. Diurnal variations in hypoxia were driven by tide and wind in the strongly enclosed waters in the head of Osaka Bay. It was found that processes of the organism decomposition, oxygen consumption and carbon dioxide generation were different in and out of the ports. In the spring and summer when the water column is stratified, surface water absorbs $\mathrm{CO}_{2}$ and bottom water stores $\mathrm{CO}_{2}$ in strongly enclosed waters. On the other hand, in the end of summer, the stored $\mathrm{CO}_{2}$ upwells to the surface and causes spontaneous emission because the north wind induces the upwelling.
\end{abstract}

\section{1. はじめに}

湾奥部の港湾水域は，市民の最も身近な親水空間“里 海”となっている.このような水域では，しばしば赤潮 が起き, またときには無酸素水が湧昇し, 青潮が発生し, 悪臭を放つこともある.

青潮は，東京湾においては頻繁に発生が確認される現 象であるが，近年では大阪湾奥部でも発生が確認されて いる（藤原ら，2005）. 青潮の発生には窪地の存在や風 による流れとの関係が指摘されている（佐々木ら， 1996 ；柿野ら，1987）。このような港湾水域の貧酸素 · 無酸素水塊について, 現状では有効な発生防止対策がな いのが現状である。

貧酸素化は，大阪湾のみならず他の内湾でも起きてお り, 貧酸素化対策は内湾の環境再生に共通する主要な課 題となっている.

中辻ら（2003）によれば，大阪湾奥部の貧酸素水塊の 挙動については, 風による貧酸素水塊の解消が見られず, 湾奥部の一般的な傾向と異なる傾向を持つことが示され ており, 貧酸素水塊の消長には複雑な要因が影響してい ることが指摘されている．また，一時的なDOの回復が 見られてもすぐに復元されることが示されている.

このように，閉鎖性内湾における研究例は数多くある が，複合的な要因が絡むことによって貧酸素水塊の消長 については未だ明らかにされていない部分も多い.さら に防波堤で囲まれた港湾等の強閉鎖性海域内の流動, 海 水交換, 貧酸素水塊の発生や消滅機構については知見が

$\begin{array}{llll}1 & \text { 正会員 } & \text { 博(理) } & \text { 奈良教育大学 准教授 教育学部 } \\ 2 & \text { 正会員 } & \text { 博(学) } & \text { 大阪工業大学 教授 工学部 } \\ 3 & \text { 正会員 } & \text { 農博 } & \text { 京都大学大学院 教授 農学研究科 } \\ 4 & \text { 修(教) } & \text { 奈良教育大学大学院 } \\ & & & \text { (現 岐阜県瑞穂市公立小学校 講師) }\end{array}$

少ないのが現状である.

そこで，本論文では港湾規模の強閉鎖性海域で発生す る貧酸素水塊対策に関連し, 現地調査を実施し, 強閉鎖 性海域の貧酸素化機構やその動態について検討した.

\section{2. 現地調査および解析}

現地調査は，大阪湾奥部に位置する新西宮ヨットハー バー（以下YHと称す）で実施した（図-1）.

\section{（1）水質調査}

水質調査は，2009年 5 月下旬から 12 月初旬まで，図-1

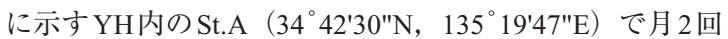
程度行った。また，2009年11月12日〜 13 日には，同地 点で 1 時間間隔の 24 時間調査を実施した。

クロロテック（JFEアレック社製 AAQ1183）により， 水温, 塩分, $\mathrm{DO}, \mathrm{pH}$, 濁度, クロロフィルの鉛直分布 を $0.1 \mathrm{~m}$ 間隔で測定した。

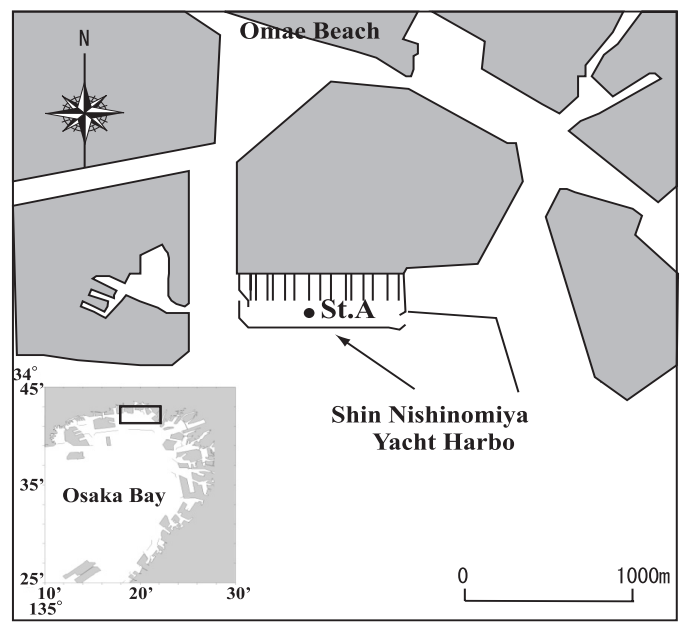

図-1 調査地点 
また，バンドーン採水器により表層から海底直上 $1 \mathrm{~m}$ まで $1 \mathrm{~m}$ 間隔で多層採水を行った。採水試料は, 公定法に したがって DIN $\left(\mathrm{NO}_{2}-\mathrm{N}, \mathrm{NO}_{3}-\mathrm{N}, \mathrm{NH}_{4}-\mathrm{N}\right), \mathrm{TP}, \mathrm{PO}_{4}-\mathrm{P}$ を分析し，三菱アナリテック社製 TN-100でTNを，島津 製作所製 TOC-VでTOCを測定した。また，滴定法によ り全アルカリ度の測定を行った（方法はJISK0400-1510:1998)。この採水調査により, 貧酸素水塊中に蓄えら れる栄養塩および二酸化炭素濃度を求めた.

\section{（2）水温連続観測}

水質調査では, 風と対応した躍層深度の変化, 湧昇が 貧酸素水塊の挙動に影響を与えていた。このため，YH

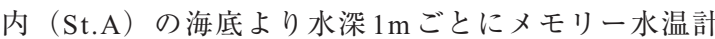
(Onset社製ホボウォーターテンププロ H20-001，精 度： $\pm 0.2^{\circ} \mathrm{C} ）$ を設置し， 10 分間隔で水温連続観測を行 った。観測期間は，2008年11月20日〜28日である。

\section{（3）風向・風速データ}

上記調査期間中の風向・風速データは, 調査対象地域 に近い国土交通省近畿地方整備局神戸港湾空港技術調査 事務所管理の神戸港波浪観測塔（六甲アイランド沖： $\left.34^{\circ} 38^{\prime} 50^{\prime \prime} \mathrm{N}, 135^{\circ} 16^{\prime} 36^{\prime \prime E}\right)$ の2 時間間隔のデー夕を提供 して頂き，解析に用いた。

\section{(4) 二酸化炭素の解析}

貧酸素水塊中では，酸素消費にともなって二酸化炭素 $\left(\mathrm{CO}_{2}\right)$ が生成され蓄積されていた（藤原，2010）。そこ で本研究では，YHにおける $\mathrm{CO}_{2}$ の挙動も調べた。

$\mathrm{CO}_{2}$ 系の各項目の值は, $\mathrm{pH}$ と全アルカリ度から計算で 求める方法である。計算式はCDIAC（Carbon Dioxide Information Analysis Center) が提供する $\mathrm{CO}_{2} \mathrm{SYS}$ （Lewis\&Wallace,1998）を用いた.

全アルカリ度は，本調査によって得られた全アルカリ 度と塩分の関係式と，田口ら（2009）による全アルカリ 度と塩分との関係式には有意な差がなかったので，後者 を用いて算出した。

計算で求めた表面海水の二酸化炭素分圧 $\left(\mathrm{pCO}_{2}\right)$ と大 気の二酸化炭素分圧 $(380 \mu \mathrm{atm})$ の差 $\left(\Delta \mathrm{pCO}_{2}\right)$ が正の とき $\left(\Delta \mathrm{pCO}_{2}>0\right)$, 海水から大気への $\mathrm{CO}_{2}$ の放出, 負の とき（ $\Delta \mathrm{pCO}_{2}<0 ）$ を，吸収とした。

また，YHのような港内海域と，港外海域の比較を行 うため，神戸市公共用水域水質調査，第五管区海上保安 本部海洋情報部の大阪湾環境調査の塩分・水温・pH ー夕を提供して頂き，これから大阪湾東部の $\Delta \mathrm{pCO}_{2}$ の 3 年間（2006〜2008年度）の平均值を求めた。

\section{3. 調査結果}

\section{（1）水質の季節変化}

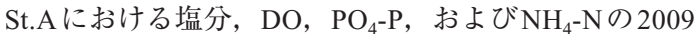
年の季節変化を図-2に示す。
塩分躍層は6月中旬から発達し，7月中旬に最も強くな った後，8月下旬から9月上旬にかけて弱くなった.

9月 21 日には一時的に塩分躍層が消滅し，表層まで高 塩分となり，下層の高塩分水が上層まで湧昇したことを 示唆している.

水深が約 $9 \mathrm{~m}$ の St.Aにおいて，5月下旬の時点で水深 $3 \mathrm{~m}$ 以深で DOが $3 \mathrm{mg} / 1$ 以下の貧酸素状態であり，6月初旬 には水深 $7 \mathrm{~m}$ 以深で DOが $1 \mathrm{mg} / 1$ 以下となった。成層の発 達に伴い，貧酸素層は上方に拡大し，8月には水深 $3 \mathrm{~m}$ 以 深でDOが3mg/1以下となった.

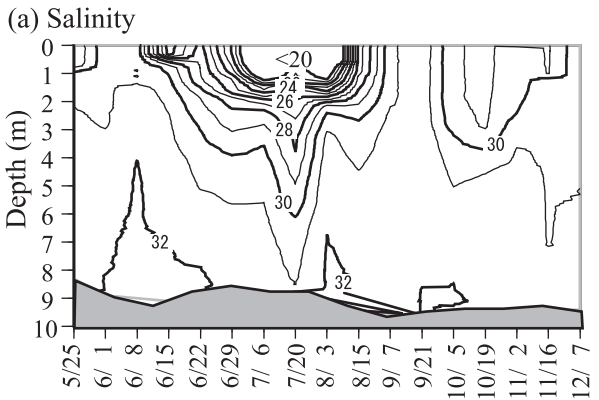

(b) DO (mg/l)

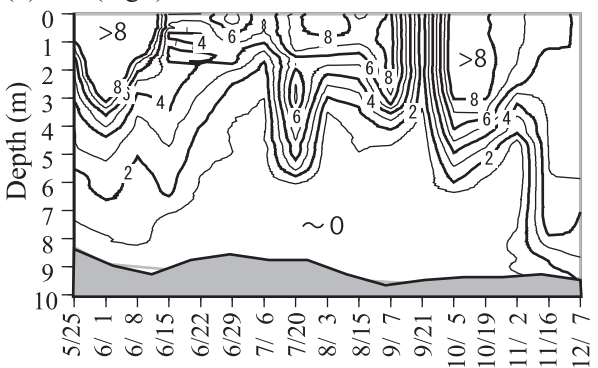

(c) $\mathrm{PO}_{4}-\mathrm{P}(\mu \mathrm{g} / \mathrm{l})$

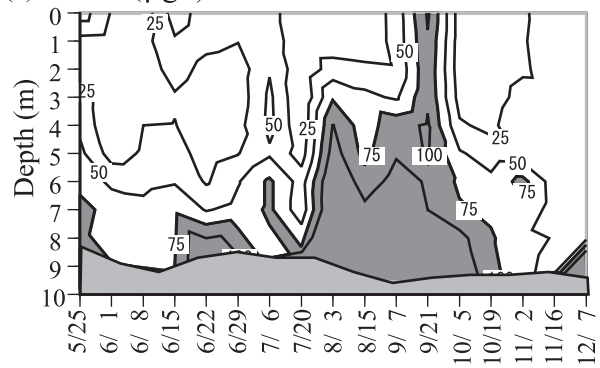

(d) $\mathrm{NH}_{4}-\mathrm{N}(\mu \mathrm{g} / \mathrm{l})$

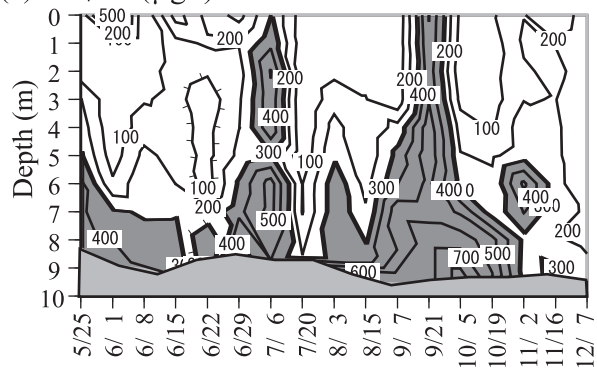

図-2 YH内（St.A）に打ける水質の季節変化（2009年） 
貧酸素層の深度に季節変化はあっても, 少なくとも 11 月まで貧酸素状態は継続していた。また，10月下旬から 11月にかけては, 中層に貧酸素水塊が形成されていた。

塩分躍層が消滅した9月 21 日には, 底層から表層まで 全層にわたってDOが $1 \mathrm{mg} / \mathrm{l}$ 以下となるとともに, $\mathrm{NH}_{4}-\mathrm{N}$ や $\mathrm{PO}_{4}$-P濃度が高くなった。

大雨に伴う流入河川水の影響によって, $\mathrm{NO}_{3}-\mathrm{N}$ 濃度が 増加することを除くと, 無機態窒素の大部分は $\mathrm{NH}_{4}-\mathrm{N}$ であった。いずれも底層で濃度が高く，表層に向かって 減少する傾向を示し, 貧酸素水塊の消長とよく対応して いる.

\section{（2）水温変動}

貧酸素水塊の動態を明らかにするために, YH内のSt.A における，風速の北方成分と水温の変動を図-3に示す.

YH内では, 大阪湾上の風による吹送に伴って, 躍層 深度が変動した。防波堤に囲まれた強閉鎖性海域である YH内のSt.Aでは，2008年11月24日〜25日にかけての北 風の連吹 (北方風速が $-4 \mathrm{~m} / \mathrm{s}$ ) により，水温躍層付近の水 深3〜 4m（海底上 $6 \sim 7 \mathrm{~m}$ 付近）の水塊が，水面付近まで 湧昇した.

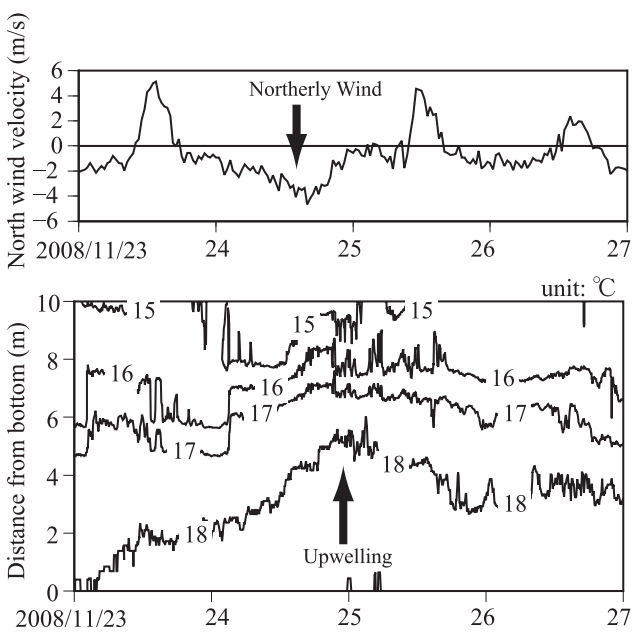

図-3 YH内（St.A）の北方風速（北風が負）と水温変動 （2008年11月23日～26日）
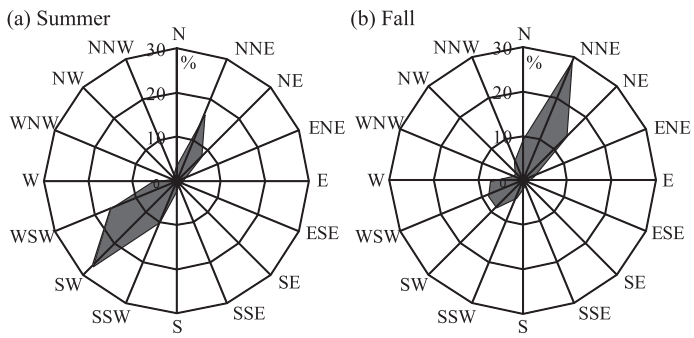

図-4 神戸港における風配図

(a) 夏季 6 8月, (b) 秋季 $9 \sim 11$ 月 (統計期間:2004～2009年)

\section{（3）大阪湾の風の特徴}

躍層の形成および貧酸素水塊の形成が顕著な夏季から 秋季にかけての神戸港の風配図を図-4に示す。

夏季（6８月）では, 南西風が卓越し, 大阪湾の沖方 向から湾奥部への風が顕著であった。また，秋季（9〜 11月）では, 北北東風が卓越し, 湾奥部から沖方向への 風が顕著であった。 大阪湾では, 夏季と秋季で卓越風向 が異なっていた。

\section{（4）貧酸素水塊の消滅過程}

防波堤で囲まれた強閉鎖性海域の底層貧酸素水塊の消 滅過を明らかにするために，2009年の成層後期の 11 月 上旬から 11 月下旬の塩分およびDOの鉛直分布を図-5に 示す.

11 月 2 日に水深 $4 \sim 5 \mathrm{~m}$ 付近にみられた塩分躍層が，日 が経つにつれて徐々に上方に移動し，11月16日には顕著 な塩分躍層は消滅した。

一方, DOについては, 11 月 2 日に水深 $6 \mathrm{~m}$ 以深にみら れた無酸素水塊 $(\mathrm{DO}$ が $0 \mathrm{mg} / \mathrm{l})$ が，塩分躍層の上方への 移動に伴い，11月12日には水深 5〜 6m，11月13日には 水深 $4 \mathrm{~m}$ まで上昇し, 中層に無酸素水塊が形成された. 逆に底層付近のDOが徐々に回復していた。その後，塩 分躍層の消滅とともに無酸素水塊が消滅した。

中層貧酸素水塊の形成は, 内湾でよくみられる現象で あるが（藤原ら，2000），防波堤で囲まれた強閉鎖性海 域でも観測された。

（5）強閉鎖性海域の $\mathrm{CO}_{2}$ の変動特性

\section{a) $\mathrm{YH}$ 内 DOと $\mathrm{pCO}_{2}$ の変動}

St.Aにおける DO, $\mathrm{pH}, \mathrm{pCO}_{2}$ の鉛直分布を図-6に示す. また，同地点の 2009年の $\mathrm{pCO}_{2}$ の季節変動を図-7に示す。

図-6に示すように，DOは底層に向かうにつれ低下し

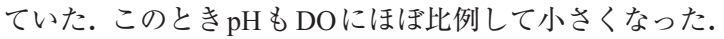
また $\mathrm{pCO}_{2}$ は, 海面では大気平衡分圧の $380 \mu \mathrm{atm}$ に近いの に対し, 貧酸素水塊中（水深 $8 \mathrm{~m}$ 付近）では, 表層 $\mathrm{pCO}_{2}$

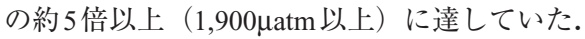
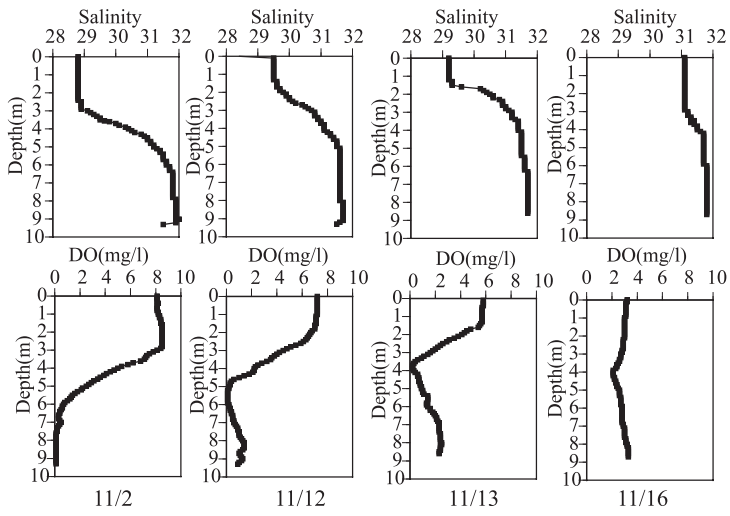

図-5 YH内（St.A）の塩分・DO鉛直分布（2009年） 

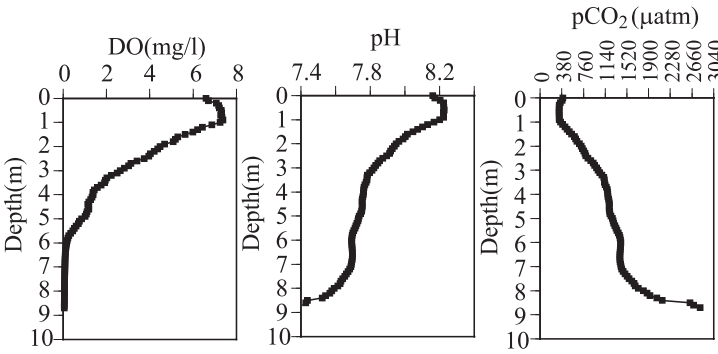

図-6 $\mathrm{YH}$ 内 (St.A) の DO, $\mathrm{pH}, \mathrm{pCO}_{2}$ の鉛直分布 （2009年8月 15 日）

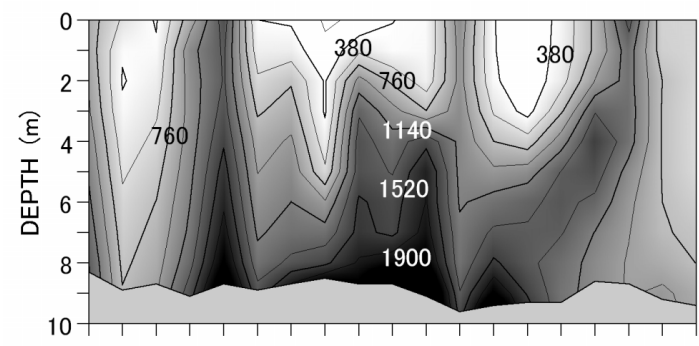

崖 耑

図-7 YH内（St.A）における $\mathrm{pCO}_{2}$ の季節変化（2009年）

図-7に示すように, $\mathrm{pCO}_{2}$ は底層の貧酸素・無酸素水塊 の形成に伴い高くなっていた。この高い $\mathrm{pCO}_{2}$ 水が，9月 21 日には上層にまで拡大し，その後，11月中旬以降に全 層でほほ同じ $\mathrm{pCO}_{2}$ となっていた。

\section{b）港内と港外の $\mathrm{CO}_{2}$ 放出・吸収}

強閉鎖性海域の港内と港外を比較するために，大阪湾 東部の 2006 年 4 月〜 2009 年 6 月までの約 3 年間の表層海 水の $\Delta \mathrm{pCO}_{2}$ の平均值を図-8に示す.

大阪港側は $\Delta \mathrm{pCO}_{2}>0$ であり, $\mathrm{CO}_{2}$ の大気への放出域 であった。一方，神戸港側は $\Delta \mathrm{pCO}_{2}<0$ であり， $\mathrm{CO}_{2}$ の吸 収域となっていた。しかし，吸収域の神戸港側でも，港 内である兵庫運河では， $\Delta \mathrm{pCO}_{2}$ が $195 \mu \mathrm{atm}$ であり，放出 となっていた。

\section{4. 考察}

\section{（1）成層の発達と DO・栄養塩濃度の季節変化}

貧酸素水塊が形成されている底層では, $\mathrm{NH}_{4}-\mathrm{N}$ P $\mathrm{PO}_{4}-\mathrm{P}$ 濃度が高くなっていた。一方，DOが過飽和となってい る表層では濃度が低くなっていた（図-2)。このことは， 防波堤で囲まれた強閉鎖性海域では，直接の水質污濁源 がなくとも，底層では，貧酸素化の進行に伴い，底質か らの溶出と有機物分解で $\mathrm{NH}_{4}-\mathrm{N}$ が生じ，底層のみならず 上層に拡大し，植物プランクトンに利用され，次の再生 生産に利用されていることが推察される.

また，9月21日の一時的な底層水の表層への湧昇（図-2)

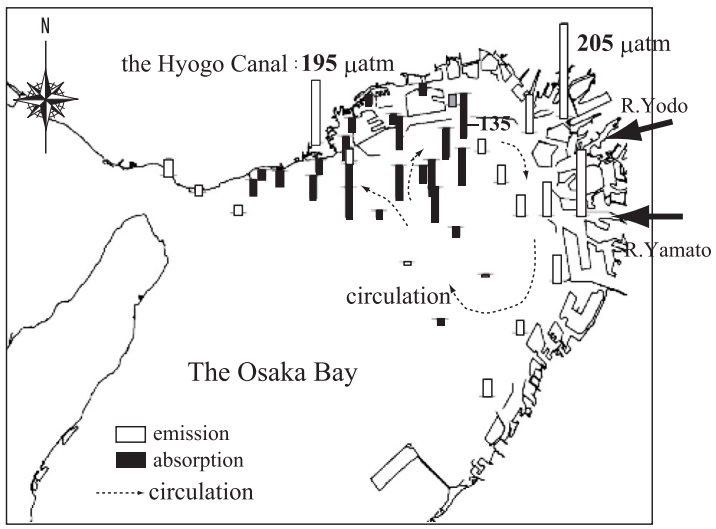

図-8 大阪湾東部の表層海水の $\Delta \mathrm{pCO}_{2}$ (2006年4月～2009年6月までの毎月の平均值)

の要因については，9月18日から日本南岸には停滞前線 があり，その南を台風14号が東進したことによって，大 阪湾では北東風が連吹していた，そのため，大阪湾奥部 では，下層水の湧昇が生じ，底層水が表層まで持ち上げ られたと推察される。

\section{（2）風による吹送と貧酸素水塊の動態}

図-3に示す，2008年11月25日の北風の連吹に伴う底 層水の水面への湧昇は，図-9に示すように，大阪湾上を 北風が連吹することにより，上層水は，湾奥部より沖方 向に流出し，逆に下層水は湾奥部に寄せられ，上昇する. そのため, YH内（St.A）には，大阪湾の下層水が防波堤 の間を通って密度流として流入し，YH内の底層水を持 ち上げる。つまり，大阪湾上の風による吹送と強閉鎖性 海域内の貧酸素水塊の動態とは連動している.

成層後期の 9〜11月にあたる YH内（St.A）では，大阪 湾上の北北東の風の卓越により，沿岸部では貧酸素水塊 が湧昇しやすい条件となっていた.

\section{（3）貧酸素水塊の発生と消滅}

貧酸素水塊の発生過程には，有機物分解に伴う酸素消 費が大きい。酸素消費は主に生物化学過程であり，バク テリアによる有機物分解（呼吸）によって酸素が消費さ

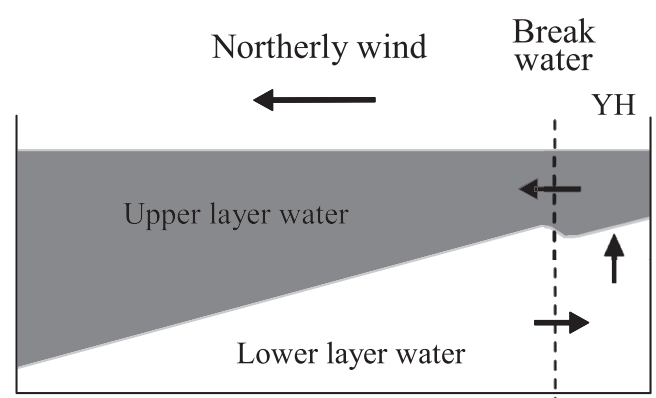

図-9 大阪湾上の北風の連吹と躍層面の変動 
れる.この呼吸は, 上層で起きる光合成の逆過程であり, 有機物と酸素から, 無機態窒素・リン（栄養塩）と二酸 化炭素が生じる（藤原, 2010). これは, 図-6のDOと $\mathrm{pCO}_{2}$ の鉛直分布が示しており, 貧酸素・無酸素化に伴い $\mathrm{CO}_{2}$ が高濃度で蓄えられていることを示す。これが, 風 による吹送に伴い, 沿岸に寄せられ, 水面まで湧昇する ことが明らかとなった。

一方，消滅過程には，図-5に示されるように，強閉鎖 性海域内の底層に形成された貧酸素水塊の下に, この水 塊よりも重い（密度の大きい）港外からの海水が防波堤 の間を通って密度流として流入し, 港内の底層貧酸素水 塊を上に持ち上げることによって, 中層貧酸素水塊が形 成される. その後, さらに上方へ持ち上げられることに よって貧酸素水塊が消滅する.

\section{（4）分酸素水塊と $\mathrm{CO}_{2}$ の放出・吸収}

大阪港側では, 淀川や大和川から流入した有機物が河 口域から沿岸部で分解され, 栄養塩となり, その後, 西 宮沖環流によって北上し, 神戸港側で再生生産による有 機物生成と栄養塩消費が起きていることを示唆している (図-8). また, 9 10月の大阪湾では, 北方向の風が卓 越することにより (図-4), 大阪湾北部の沿岸域では, 湧 昇となる。したがって, 成層期の 8 月下旬までに底層に 蓄えられた $\mathrm{CO}_{2}$ (図-7）が, 水面に湧昇し, 大気への $\mathrm{CO}_{2}$ の放出となると推察される.

\section{5. 結論}

本研究では, 強閉鎖性海域の貧酸素水塊の発生機構と 動態に関して水質調査, 連続観測およびデータ解析を行 った. その結果，防波堤で囲まれた強閉鎖性海域のよう に河川からの直接の水質污濁源がなくとも, 底層では, 貧酸素化に伴い, 底質からの栄養塩の溶出と有機物分解 による栄養塩の生成が生じ, 鉛直循環や湧昇により, 次 の再生生産に利用されていることが明らかとなった。ま た, 底層の酸素消費と二酸化炭素生成は連動しており,
貧酸素・無酸素水塊中には $\mathrm{CO}_{2}$ が高濃度で蓄えられてい ること, および風による吹送に伴う港外の躍層面の昇降 の繰り返しによって, 強閉鎖性海域内に形成された底層 の貧酸素水塊が動き, ときには水面まで湧昇することが 明らかとなった。これらのことから, 貧酸素化が問題と なる沿岸域が $\mathrm{CO}_{2}$ の吸収源か, 放出源かを明らかにする ことは, 沿岸の環境保全にとって重要である.

今後の課題としては, 貧酸素水塊の季節的・場所的な 違いとともに, $\mathrm{CO}_{2}$ 吸収・放出量（フラックス）を明ら かにする必要があると考えている.

謝辞: 本研究は大阪湾広域臨海環境整備センターの平成 20 年度及び平成 21 年度「大阪湾圈域における海域環境の 再生・創造に係る研究の助成事業」により行われた。

\section{参 考 文 献}

藤原建紀・高橋鉄哉・山田佳昭・金子昭夫 (2000) : 東京湾の 貧酸素水塊に外洋の海況変動が及ぼす影響, 海の研究, 9, pp. 303-313.

藤原建紀 (2010) : 内湾の貧酸素化と青潮, 沿岸海洋研究, 48, 印刷中.

藤原隆一 - 小竹康夫 - 上田悦子 - 知振佐苗 (2005) : 大阪湾で 発生した青潮の現地調査, 海洋開発論文集, No. 21, pp. 361-366.

柿野 純・松村泉月・佐藤善徳・加瀬信明（1987）：風による 流れと青潮の関係, 日本水産学会誌, No. 53, pp. 14751481 .

Lewis and Wallace (1998) : Program Developed for $\mathrm{CO}_{2}$ System Calculations, Carbon Dioxide Information Analysis Center, pp. 1-21.

中辻啓二 · 入江政安 - 西田修三 - 湯浅楠勝 (2003)：大阪湾奥 部閉鎖性海域の貧酸素水塊の現地調査, 水工学論文集, No. 47, pp. 1285-1290.

佐々木 淳・磯部雅彦・渡辺 昇・五明美智男（1996）：東京湾 における青潮の発生規模に関する考察, 海岸工学論文集, No. 43, pp. 1111-1115.

田口二三生 - 藤原建紀 - 山田佳昭 - 藤田弘一 - 杉山雅人 （2009）：沿岸海域のアルカリ度, 沿岸海洋研究, 47, pp. $71-75$. 